\title{
International Journal of Economics, Business and Management Research
}

Vol. 6, No.01; 2022

ISSN: $2456-7760$

\section{Determinants of Tax Avoidance on Consumption Business Sector in Indonesia}

\author{
Sigit Handoyo \\ Accounting Department, Universitas Islam Indonesia \\ sigit.handoyo@uii.ac.id \\ Ahada Nurfauziya \\ Accounting Department, Universitas Islam Indonesia \\ ahadanur@uii.ac.id \\ Prila Eki Rolanisa \\ Accounting Department, Universitas Islam Indonesia \\ prilaeki03@gmail.com
}

doi: 10.51505/IJEBMR.2022.611

URL: http://dx.doi.org/10.51505/IJEBMR.2022.6111

\begin{abstract}
Tax avoidance by companies in Indonesia has often been done. Even though this activity is classified as legal, it is basically done by violating tax regulations. This study is intended to explore further what factors influence tax avoidance activities in consumption sector manufacturing companies listed on IDX in the 2016-2019 period. The analysis was carried out using multiple regression analysis. The results of the study prove that gender, audit committee and firm size have a positive and significant effect on tax avoidance. While leverage and profitability cannot affect tax avoidance activities.
\end{abstract}

Keywords: tax avoidance, gender, audit committee, leverage, profitability, firm size.

\section{Research Background}

Tax is one of Indonesia's largest sources of state revenue. This opinion is supported by research by Mustikasari (2007) which explains that currently $80 \%$ of state revenues come from tax revenues contained in the State Revenue and Expenditure Budget (APBN). This proves that taxes are a reliable source of state revenue. According to Article 1 paragraph 1 of Law Number 16 of 2009 concerning the fourth amendment to Law Number 6 of 1983 concerning General Provisions and Tax Procedures, it is explained that taxes are national obligations that must be paid by individuals or entities and are coercive, used for state needs. and welfare of the people without receiving direct compensation.

Taxes are a very important source of state financial income. With the increase in state revenues originating from the tax sector, the government always strives to improve the existing tax system so that it continues to run in a better direction. The government relies on taxes as state revenue that can be used to finance state development, therefore the government must optimize state revenues from the tax sector. There are still many taxpayers who are reluctant to pay taxes and this leads to a decrease in national tax revenues. Taxpayers are reluctant to pay taxes according 


\section{International Journal of Economics, Business and Management Research}

Vol. 6, No.01; 2022

ISSN: $2456-7760$

to actual conditions and fight taxes by reducing existing tax payments by Darmawan \& Sukartha (2014).

According to CNBCIndonesia.com (2020), tax revenue data in the last 4 years has always been short and never reached the target. Looking back, the tax revenue shortfall has been around for a long time. It is known that the realization in 2016 was Rp 1,283 trillion or $83.4 \%$ of the Rp 1,539 trillion target and experienced a shortfall of Rp 256 trillion. Realization in 2017 was IDR 1,147 trillion or $89.4 \%$ of the target of IDR 1,283 trillion and experienced a shortfall of IDR 136 trillion. Realization in 2018 was IDR 1,315.9 trillion or 92\% of the target of IDR 1,424 trillion and experienced a shortfall of IDR 108 trillion. The 2019 realization was Rp. 1,332.1 trillion or $84.4 \%$ of the target of Rp. 1,577.6 trillion and experienced a shortfall of Rp. 245.5 trillion.

Based on CNBCIndonesia.com (2020) data, it can be seen that tax revenue in 2019 experienced a considerable shortfall compared to the previous year. The government needs to anticipate this so that it does not continue into the following year. This lack of tax revenue is caused by problems that should receive special attention from the government, namely the practice of tax avoidance through underground economy activities and global tax avoidance practices. The underground economy is a legal and illegal activity that is hidden from the official authorities to avoid paying existing taxes.

Many companies in Indonesia are doing tax avoidance to minimize the tax burden that should be paid. Based on nasional.kontan.co.id (2020) Tax Justice Network Report, as a result of tax evasion, Indonesia suffers a loss of US $\$ 4.86$ billion annually or equivalent to Rp. 68.7 trillion. Companies do tax avoidance to minimize all costs that exist in the company including the tax burden. The existence of a tax burden will reduce the profits distributed to the management and owners of the company's capital. The high tax burden encourages many companies to carry out tax management so that the taxes paid are lower. Therefore, managers minimize the tax burden by avoiding tax. On the other hand, companies view that tax avoidance provides large economic benefits and an inexpensive source of financing Armstrong et al., (2015).

Based on nasional.kontan.co.id (2014) one of the many cases of companies in Indonesia that have avoided tax is PT CC Indonesia. After an audit conducted by the Directorate General of Taxes, the Ministry of Finance explained that in 2002-2006 there was a significant increase in costs. This increase in costs is caused by a cost burden, causing taxable income to decrease and tax payments to decrease. The expense was an advertisement used from 2002-2006 with a total of Rp 566.84 billion. According to CC's calculation, the total taxable income earned was Rp. 492.59 billion, CC's total taxable income for that period should have been Rp. 603.48 billion. The DGT then calculated the CC's shortfall in income tax (PPh) with a difference of Rp 49.24 billion.

Based on nasional.kontan.co.id (2014) the existence of this case proves the existence of tax evasion by PT CC because it wants to reduce the tax costs that will be deposited. The tax avoidance method used by PT CC is carried out through transfer pricing activities. By increasing the burden of advertising costs, the net profit generated by PT CC will be small and lead to lower 


\section{International Journal of Economics, Business and Management Research}

Vol. 6, No.01; 2022

ISSN: $2456-7760$

tax suppression. PT CC has had a negative effect on the Indonesian state, because if left unchecked, it will cause a significant reduction in state revenues from taxes.

Because there are inconsistencies in the results of previous studies, researchers are interested in bringing up the issue of tax avoidance and reviewing it with the variables that have been described. The government needs to overcome the problem of tax avoidance because it can cause state revenues to decrease and take firm action against taxpayers so as not to avoid tax evasion, this opinion is supported by Alfaruqi, Sugiharti, \& Cahyadini (2019)

This study uses manufacturing companies in the consumer goods industry sector which are listed on the Indonesia Stock Exchange (IDX). This type of manufacturing company was chosen because it is a company sector that contributes greatly to state tax revenues when compared to sectors such as plantations, finance, and mining. Manufacturing companies are also on the inspection list of the Directorate General of Taxes which are frequently inspected.

According to a survey conducted in 2012 as many as 4,000 foreign investment companies only reported their taxes but did not have the amount of tax owed because they had losses for 7 consecutive years and manufacturing companies engaged in these fields Prakosa (2014).

Therefore, there is a need for research to prove what factors are the determinants of manufacturing companies in the consumer goods industry sector in doing tax avoidance. The period in this study describes the latest situation, namely 2016-2019.

\section{Literature Review}

\section{Previous Research}

Research on the factors that influence Tax Avoidance has been carried out by several researchers in Indonesia. In (2016) Dewinta \& Setiawan conducted a study that aims to determine the effect of firm size, firm age, leverage, profitability, and sales growth on tax avoidance. The results of the study stated that firm size, firm age, profitability, and sales growth had a positive effect on tax avoidance, while leverage had no effect on tax avoidance.

In 2017 several researchers conducted a similar study including Winasis \& Yuyetta (2017) with the results showing that the executive gender variable has a significant impact on tax avoidance, executive gender diversity has a negative effect on the value of large companies, and the tax avoidance variable has no significant effect on tax avoidance. firm value and tax avoidance have no effect as mediating variables. Sarra (2017) The results of the study state that the audit committee has a significant positive effect on tax avoidance, while independent commissioners have no significant positive effect and accounting conservatism has a significant negative effect on tax avoidance. Amri (2017) The results of the study prove that management compensation has a negative effect on tax avoidance. Furthermore, the use of moderating variables (ie executive gender diversity and executive risk) suggests that if compensation is given to executives who have at least one female director who exhibits gender diversity and risk preference for risktakers, compensation will have a positive impact on corporate tax avoidance. 


\section{International Journal of Economics, Business and Management Research}

Vol. 6, No.01; 2022

ISSN: $2456-7760$

In 2018 several researchers conducted a similar study including Putra \& Nasrizal (2018). The results of the study prove that executive character, gender diversity, and debt ratios affect earnings management, while political connections and executive compensation do not affect earnings management. Then the executive character, executive compensation, gender diversity, and debt ratio affect tax avoidance, while political connections have no effect on tax avoidance. Nugrahitha \& Suprasto (2018) The results of the study prove that leverage, corporate governance, and executive character have a positive effect on tax avoidance, while profitability has no effect on tax avoidance. Budianti \& Curry (2018) results show that profitability has a negative effect on tax avoidance, liquidity has a positive effect on tax avoidance, and capital intensity has a negative effect on tax avoidance.

In 2019 several researchers conducted a similar study including Noviyani \& Muid (2019). The results show that return on assets, leverage, capital intensity, and institutional ownership has a significant effect on tax avoidance. Mulyani et al., (2019) The results of this study state that accounting conservatism, capital intensity have no effect on tax avoidance, while firm size has a positive effect on tax avoidance. Rifai \& Atiningsih (2019) The results of the study show that profitability, capital intensity, and earnings management have a negative effect on tax avoidance, while leverage has no effect on tax avoidance.

\section{Agency Theory}

Agency theory was first put forward by Stephen Ross and Barry Mitnick at approximately the same time around 1973. Stephen Ross put forward agency theory from an economic perspective and Barry Mitnick put forward agency theory from an institutional perspective by Okta Arianti (2013).

Mitnick (2013) stated Ross introduced the study of agency in terms of problems of compensation contracting; the agency was seen, in essence, as an incentives problem. Mitnick introduced the now common insight that institutions form around agency, and evolve to deal with the agency, in response to the essential imperfection of agency relationships: Behavior never occurs as it is preferred by the principal because it does not pay to make it perfect. But society creates institutions that attend to these imperfections, managing or buffering them, adapting to them, or becoming chronically distorted by them. Thus, to fully understand agency, we need both streams -- to see the incentives as well as the institutional structures.

Agency theory occurs between principals and agents who have different interests and cause agency conflicts themselves. The agent in question is the manager of the company, namely management, while the principal is the shareholder of the company. Shareholders provide funds to the company, then management is tasked with managing funds in the company and providing financial reports to be reported to shareholders by Jensen \& Meckling (1976).

Management must run and manage the company well to generate large profits so that management will get compensation from shareholders, but if the management of funds in the company does not satisfy the shareholders, the shareholders will terminate the previously agreed contract with the company. The existence of compensation that will be obtained makes management have a personal goal to get big profits. This is supported by research by Melisa \& 


\section{International Journal of Economics, Business and Management Research}

Vol. 6, No.01; 2022

ISSN: $2456-7760$

Tandean (2015) agency theory believes that humans have a selfish nature and always prioritize themselves over others.

Tessa \& Harto (2016) stated management certainly has a selfish nature to achieve personal goals. Management tries to compile the company's financial statements to make it look good in the eyes of shareholders, by committing various frauds such as manipulating data in financial statements to achieve personal goals. Management prepares financial statements by ignoring accounting principles, causing irregularities. This causes frequent conflicts between the principal and the agent.

Masri \& Martani (2013) stated tax avoidance by a company is influenced by the difference in interests between management and shareholders (agency theory). Shareholders formulate policies and make decisions to avoid the tax burden, in contrast to management who has a personal goal to benefit from the company. Management as an agent conducts tax avoidance by increasing the efficiency of tax payments in accordance with tax laws and regulations.

\section{Feminism Theory}

Wollstonecraft (1792) describes a European society that is experiencing a decline where women are confined in the home are not given the opportunity to enter the labor market and do household work. Meanwhile, men are given the freedom to develop themselves as optimally as possible. In fact, if women are given the same opportunity, they can develop themselves optimally, as long as women are also given the same education as men

According to Asmaeny (2007) feminism came from the Latin word femina or women. Feminism refers to the equality of men and women and the movement to obtain rights as women. The term feminine began to be used in 1890. Without having to look at the nature and nature of women and men, this theory assumes that women demand equality from men from various aspects of life. So far, there are still many people who think that the position of men is higher than women. Kamayanti (2013) suggested that feminism theory pays attention to gender behavior, its effect on company performance and financial statements which are part of critical accounting theory.

The existence of gender between women and men will certainly make a person's personality and behavior in decision making different. This is supported by research by Novita (2016) which explained that men tended to dare to take risks in decision making, while women are more careful in taking risks in decisions by Novita (2016).

\section{Tax Avoidance}

According to Stiglitz (1986), there are three basic principles of tax avoidance on income tax includes the following: (1) postponement of tax; (2) utilization of the law on imposition of different income tax for different income levels, and (3) utilization of the law on imposition of different income tax for different resource of income. However, tax evasion generally uses variations of one or more of these principals. This is done in order to cover the truth, in order to avoid taxes. One of the things that can reduce the opportunity for tax avoidance is the periodic renewal of tax regulations by Stiglitz (1986). 


\section{International Journal of Economics, Business and Management Research}

Vol. 6, No.01;2022

ISSN: $2456-7760$

Tax avoidance is an effort made by taxpayers to reduce the tax burden they will pay. Taxpayers do various ways to avoid tax with the aim of reducing the tax burden without violating existing laws. This opinion is supported by Pohan (2013) who asserted that tax evasion is carried out legally by taxpayers using methods and techniques to take advantage of legal weaknesses so as not to conflict with tax provisions by reducing the amount of tax that must be paid. Dewi \& Sari (2015) revealed that tax evasion is carried out by taxpayers to minimize the amount of taxes that must be paid, so as to ease the burden of taxes that must be paid. This has a big impact on the state, namely the reduction in state revenues.

In the practice of tax avoidance, a company carries out a tax savings scheme to reduce the tax burden that must be paid. The scheme carried out by the company according to Rahayu (2011) there are several ways. The first is transfer pricing, which is a tax scheme used by companies to formulate policies in determining transfer prices from existing transactions, such as goods, services, intangible assets and financial transactions carried out by companies. Companies use transfer pricing to optimize company profits by shifting company profits from high-tax countries to low-tax countries. This is very beneficial for the company because the company can manipulate the financial statements so that it can report losses and the company does not need to pay taxes. This transaction is usually carried out by fellow companies that have a special relationship. According to Rahayu (2011) in its application there are two groups of transactions in transfer prices, namely intercompany and intracompany. Intercompany is the transfer price made by a company with another company that has a special relationship. Intercompany transactions can be carried out in one country and in different countries, while intracompany transactions are transfer prices made between departments within one company.

The second is Thin Capitalization, which is a tax scheme where the company has less capital than debt, so that the company's debt tends to be larger than the company's capital. Thin capitalization performs tax avoidance actions by financing their subsidiaries covertly with capital in the form of loans that exceed reasonable limits. This causes the company to reduce the interest expense so that the tax payment paid by the company will be smaller.

The third is Treatty Shopping. This scheme is carried out by taking advantage of the treaty benefit. The benefits of this agreement are in the form of facilities which are an agreement between 2 countries and only domestic taxpayers can enjoy them. Companies without a tax treaty use subsidiaries located in other countries to carry out investment activities, therefore these companies can take advantage of existing facilities and obtain low tax rates.

The fourth is the Controlled Foreign Corporation (CFC). In this scheme a company operates abroad but in practice it is controlled by a domestic taxpayer. Domestic taxpayers take advantage of countries with low taxes and establish companies in those countries. Taxpayers take advantage of companies located abroad to delay the confirmation of taxable income to avoid paying tax debts. Taxpayers also use this CFC to avoid paying dividends.

\section{Gender}

Gender is the difference between men and women in roles, functions, rights, responsibilities, and behaviors that are shaped by the social, cultural and customary values of a community group and 


\section{International Journal of Economics, Business and Management Research}

Vol. 6, No.01; 2022

ISSN: $2456-7760$

can change according to time and local conditions. In the gender board, men are more suitable to occupy high and important positions in the company because men have high abilities and intelligence, while women have few positions in the company because many think that women are not as smart as men Deaux \& Ernswiller in Kusumastuti et al. (2008).

The company will appear to have performed well when there is a proportion of female and male boards. The more diverse the proportion of women and men, the better the company's performance and the better its management capabilities. Companies that have different gender proportions or have at least 1 female board of commissioners or directors will increase company efficiency through tax avoidance by Amri (2017).

\section{Audit Committee}

Based on Regulation of the Financial Services Authority Formation and Guidelines for the Work Implementation of the Audit Committee (2015) The Audit Committee for public company is a committee formed by and responsible to the Board of Commissioners in helping carry out the duties and functions of the Board of Commissioners. In forming the audit committee, the board of commissioners appoints a minimum of 3 people consisting of a chairman who is an independent commissioner and 2 other members from external parties. The role of the audit committee is very important for corporate governance. The audit committee is tasked with supervising and helping reduce opportunities for manipulation of financial statements by managers. The audit committee functions to help companies exercise control effectively so as to create financial reports and good corporate governance Kurniasih \& Sari (2013). The audit committee assists the company in disclosing information according to the actual situation.

\section{Leverage}

Leverage is the company's ability to pay debts and pay off its debts Sartono (2010). Companies use leverage to measure and determine the company's debt ratios, both short term and long term Kurniasih \& Sari (2013). High leverage will result in high company debt. If the company's leverage is high, the company depends on debt to run the company's operations. The company can reduce its tax burden through debt that depends on the interest expense on the company's loans. This causes the company's taxable income to decrease with the interest expense.

\section{Profitability}

The company's ability to generate profits is called profitability. The profits generated by the company reflect the company's success in running the company's operations. The company's profitability is certainly related to the existence of tax avoidance by the company. Profitability is one of the company's performance measurements.

\section{Company Size}

Ngadiman \& Puspitasari (2017) suggested that company size is used to classify the size of the company. The size of the company is divided into 3 categories, namely large companies (large firms), medium companies (medium-size) and small companies (small firms). Companies use company size to determine the size of the company which can be seen from the sales value, capital value, total asset value, number of employees, and others Saifudin \& Yunanda (2016). 


\section{International Journal of Economics, Business and Management Research}

Vol. 6, No.01; 2022

ISSN: $2456-7760$

\section{Research Hypothesis}

\section{The Effect of Gender on Tax Avoidance}

The increasing proportion of women in holding positions in companies is explained by feminism theory which will have an impact on various decisions, including in the field of taxation, namely tax avoidance. An increase in the percentage of women directly affects the level of company compliance because women tend to be careful so that they can reduce the risks that exist in the company Luthans (2006).

Women tend to avoid risk and are always careful so that women are more careful than men in making decisions, including those related to taxation. Feminism theory states that women and men have equal degrees so that women are also entitled to lead and occupy important positions in the company by Yulianti et al., (2018).

Companies that have different gender proportions or have at least 1 female board of commissioners or directors will increase company efficiency through tax avoidance. According to Robinson \& Dechant (1997) companies that have at least 1 female board of commissioners or directors are considered to have more skills related to company operations and other policies, these skills will affect the amount of tax that will be paid by the company and will increase the company's tax avoidance ability. Thus, the higher the proportion of women who have important positions on the board of commissioners and the board of directors, the higher the tax avoidance by the company.

Based on research that has been done by Amri (2017) and supported by Winasis \& Yuyetta (2017) stated that gender had a significant effect on tax avoidance. Based on the description above, the hypothesis in this study can be formulated as follows:

H1: Gender-Female has a positive effect on tax avoidance.

\section{Influence of the Audit Committee on Tax Avoidance}

Based on the IDX circular number SE008/BEJ/12-2001 regarding the membership of the audit committee, it is stated that there must be at least 3 members of the company's audit committee, including the chairman of the audit committee. The audit committee is an important part of the company that is appointed and dismissed by the company's board of commissioners, therefore the structure and selection of audit committee membership is the responsibility of the board of commissioners.

If the number of audit committees is high, then the tax avoidance carried out by managers in the company is also high, this allows the audit committee not to work optimally because it is under pressure from the board of commissioners and the many audit committees will make them work ineffectively so that more and more audit committees the more tax evasion by the company.

Based on research that has been done by Sarra (2017) and supported by Mulyani et al., (2018), it is stated that the audit committee had a positive effect on tax avoidance. From the description above, it can be formulated the hypothesis in this study as follows: 


\section{International Journal of Economics, Business and Management Research}

Vol. 6, No.01; 2022

ISSN: $2456-7760$

H2: The Audit Committee has a positive effect on tax avoidance.

\section{Effect of Leverage on Tax Avoidance}

Leverage is the company's ability to pay its debts. The company must be able to control and manage all the assets in the company, otherwise the company will have debt and must pay it off. Companies use leverage to measure and determine the ratio of short-term and long-term corporate debt.

Companies can reduce the tax burden and make tax savings to maintain the number of shares outstanding through leverage. If the company's leverage is high, the company depends on debt in carrying out the company's operational activities. High leverage causes the company's debt to be large. A large debt will make the interest expense on the company's loan increase, this is used by the company to make optimal tax savings.

The existence of this interest expense will reduce the company's tax burden, so the company can reduce its tax burden through debt that depends on the interest expense on company loans. This causes the company's taxable income to decrease with the interest expense and the company will maximize its debt to finance the company's operations so that the company can avoid tax. So, the higher the leverage, the higher the tax avoidance by the company.

Based on research conducted by Nugrahitha \& Suprasto (2018) and supported by Noviyani \& Muid (2019), it is stated that leverage had a positive effect on tax avoidance. From the description above, it can be formulated the hypothesis in this study as follows:

H3: Leverage on go public company has a positive effect on tax avoidance

\section{The Effect of Profitability on Tax Avoidance}

Profitability is used by companies to generate profits or company profits. The ratio used to determine profitability is Return On Assets (ROA). ROA is related to the existence of profits in the company and the company's income tax burden. If the company's ROA is high, then the company's net profit and profitability will also be high. High profits reflect the high taxes that must be paid by the company in accordance with the increase in company profits. High corporate profits will make it easier for the company to manage the company's profits, and this profit can be used by the company to pay the tax burden that must be paid.

Therefore, companies tend not to do tax avoidance because the company's profit is high and the company can pay its income tax. This is supported by the opinion of Prakosa (2014) which explains that profitability can affect tax planning carried out by companies. The company will get optimal tax if the company has good planning. If the company tax is optimal, the company has a tendency not to practice tax avoidance. So, the higher the profitability, the lower the tax avoidance by the company.

Based on research conducted by Budianti \& Curry (2018) and supported by Rifai \& Atiningsih (2019), profitability had a negative effect on tax avoidance. From the description above, it can be formulated the hypothesis in this study as follows: 


\section{International Journal of Economics, Business and Management Research}

Vol. 6, No.01; 2022

ISSN: $2456-7760$

H4: Profitability has a negative effect on tax avoidance.

\section{Effect of Firm Size on Tax Avoidance}

Agency theory arises because of the difference in interests between the principal and agent of a company related to company performance. The principal is the shareholder who wants the company to run well, while the agent is the management who always tries to compile financial reports in various ways so that the financial statements look good in the eyes of shareholders. Management has a personal goal to take advantage of the company by making irregularities and compiling financial reports without regard to existing accounting principles.

If the company's assets are large, the resources owned by the company are also greater than companies with small assets. The large number of company assets reflects the company's better performance in the long term, so that the company is able to generate greater profits.

The increase in company profits is of course accompanied by an increase in the income tax burden that must be paid by the company. This encourages companies to avoid tax by managing their tax burden. So, the larger the size of the company, the higher the tax avoidance by the company.

Based on research conducted by Mulyani et al., (2019) and Nur \& Subardjo (2020) that firm size had a positive effect on tax avoidance. From the description above, it can be formulated the hypothesis in this study as follows:

H5: Firm size has a positive effect on tax avoidance.

\section{Research Methods}

The population used in this study are manufacturing companies in the consumer goods industry sector listed on the Indonesia Stock Exchange (IDX) obtained through the Indonesian Stock Exchange (IDX) gallery on the Indonesia Stock Exchange website, namely www.idx.co.id. The data used is secondary data taken from the company's financial statements for 4 years, namely 2016-2019. The data obtained for 4 years aims to compare the condition of the company for 4 years and to obtain the latest data regarding the existence of corporate tax avoidance.

The sampling of this research was carried out using purposive sampling method, namely the sampling was selected based on certain criteria that had been determined by the researcher. Some of the specified sample criteria are as follows:

1. Manufacturing companies in the consumer goods industry sector listed on the Indonesia Stock Exchange (IDX) during the 2016-2019 period.

2. Companies that provide complete data based on the variables to be studied.

3. Companies that display their financial statements in rupiah currency.

4. The company did not suffer losses before tax in a row for the 2016-2019 period.

5. The company is not in a state of delisting or suspended during the 2016-2019 period. 


\section{International Journal of Economics, Business and Management Research}

Vol. 6, No.01; 2022

ISSN: $2456-7760$

\section{Results and Discussion}

In this study, secondary data is used in the form of annual reports of manufacturing companies in the food and beverage consumer goods industry that are listed on the Indonesia Stock Exchange for the 2016-2019 period. The sample used is purposive sampling method by determining the criteria that have been determined by the author. After selecting the sample according to the specified criteria, 32 out of 61 companies were found that met the sample criteria. The data that meet the criteria are 128 data (32 companies x 4 years). Sample selection criteria can be seen in table 1 below:

Table 1

Sample Selection Criteria

\begin{tabular}{|l|l|l|}
\hline No & Criteria & Total \\
\hline 1. & $\begin{array}{l}\text { Manufacturing companies in the consumer goods industry sector } \\
\text { listed on the Indonesia Stock Exchange (IDX) for the 2016-2019 } \\
\text { period }\end{array}$ & 61 \\
\hline 2. & $\begin{array}{l}\text { Companies that do not provide complete data based on the } \\
\text { variables studied }\end{array}$ & $(8)$ \\
\hline 3. & $\begin{array}{l}\text { Companies that do not display financial statements in rupiah } \\
\text { currency }\end{array}$ & $(6)$ \\
\hline 4. & Companies that suffer losses before tax for the 2016-2019 period & $(15)$ \\
\hline & Number of sample companies & 32 \\
\hline & Total data for 2016-2019 (32 companies x 4 years) & 128 \\
\hline
\end{tabular}

Source: Processed Data, 2020

\section{Descriptive statistics}

Descriptive statistical tests are used to provide a description of each research variable that has been studied starting from the minimum, maximum, average, and standard deviation values. In this study, there are 6 variables consisting of 1 dependent variable, namely tax avoidance and 5 independent variables, namely gender, audit committee, leverage, profitability and company size. The results of descriptive statistical analysis can be seen in table 2 which is presented below:

Table 2

Descriptive Statistics Test Results

\begin{tabular}{|l|l|l|l|l|l|}
\hline & $\mathrm{N}$ & Min & Max & Mean & Std. Deviation \\
\hline X1_Gender & 128 & 0 & 1 & & \\
\hline X2_Audit Committee & 128 & 3 & 4 & 3.05 & .212 \\
\hline X3_Leverage & 128 & .023 & 2.910 & .74045 & .618087 \\
\hline X4_Profitability & 128 & -.001 & .921 & .13829 & .147874 \\
\hline X5_Firm Size & 128 & 26.637 & 32.201 & 28.96809 & 1.409144 \\
\hline Y_Tax Avaoidance & 128 & .126 & .386 & .25909 & .037553 \\
\hline Valid N (listwise) & 128 & \multicolumn{5}{|l|}{} & & \\
\hline
\end{tabular}

Source: SPSS output results, 2020 


\section{International Journal of Economics, Business and Management Research}

Vol. 6, No.01; 2022

ISSN: $2456-7760$

Based on the table, the results of descriptive statistical tests can be explained as follows:

1. In this study, the dependent variable is tax avoidance. The value of the minimum tax avoidance of 0.126 was obtained by PT Wilmar Cahaya Indonesia Tbk (CEKA) in 2016 which means the company has the lowest tax burden and a high level of tax avoidance, while the maximum value of 0.386 was obtained by Chitose Internasional Tbk (CINT) in 2018 which shows that the company has the highest tax burden and the lowest level of tax evasion. The average tax avoidance that has been carried out by manufacturing companies in the consumer goods industry sector is 0.25909 in the 2016-2019 period and the standard deviation is 0.037553 . It can be seen that the average is greater than the standard deviation value, this means that the tax avoidance data is homogeneous.

2. There are five independent variables in this study, the first is gender. The minimum gender value is 0 which means the company has a male board of commissioners and directors, while the maximum gender value is 1 which means that the company has at least one female board of commissioners and directors.

3. The audit committee has a minimum score of 3 which indicates that the audit committee in the company has the least number of members and a maximum value of 4 means that the company has the highest audit committee compared to other companies. The average value of the audit committee is 3.05 during the 2016-2019 period, while the standard deviation is 0.212 . If it is seen that the average value of the audit committee is greater than the standard deviation, it shows that the audit committee data is homogeneous.

4. Leverage has a minimum value of 0.023 obtained by PT Wilmar Cahaya Indonesia Tbk (CEKA) in 2019, and a maximum value obtained by PT Unilever Indonesia Tbk (UNVR) of 2,910 in 2019. The higher the DER ratio, the higher the composition of the company's debt. The average value for the leverage variable is 0.74045 and the standard deviation is 0.618087 . The average value of leverage is greater than the standard deviation, thus indicating that the leverage data is homogeneous.

5. The minimum profitability value of -0.001 obtained by PT Kimia Farma Tbk (KAEF) in 2019 means that the company has the lowest profit compared to other companies and the maximum value is obtained by PT Merck Tbk in 2018 (MERK) which shows that the company has the investment ability to bring in high profit of 0.921 compared to other companies. The average profitability value is 0.13829 and the standard deviation is 0.147874 for the $2016-2019$ period. It can be seen that the standard deviation is greater than the average value of profitability, which means that the profitability data is heterogeneous.

6. The company size with a minimum value of 26,637 was obtained by PT Buyung Poetra Sembada Tbk (HOKI) in 2016 meaning that the company has the lowest total assets compared to other companies, and the maximum size of the company value of 32,201 was obtained by PT Indofood Sukses Makmur Tbk (INDF) in 2018 which shows that the company has high total assets compared to other companies. The average value of the company size is 28.96809 and the 
standard deviation is 1.409144 . These data indicate that the average company is greater than the standard deviation, so it can be seen that the company size data is homogeneous.

\section{Classic assumption test}

\section{Normality test}

The normality test is seen from the level of significance using the Kolmogorov-Smirnov test, if the Kolmogorov-Smirnov test $>0.05$ then the data is normally distributed, and if the significance is $<0.05$ then the data is not normally distributed. The results of the normality test can be seen in table 3 which is presented below:

Table 3

Normality Test Results

One Sample Kolmogorov-Smirnov Test

\begin{tabular}{|l|l|}
\hline & Standardized Residual \\
\hline $\mathrm{N}$ & 128 \\
\hline $\begin{array}{l}\text { Asymp. Sig. (2- } \\
\text { tailed) }\end{array}$ & .072 \\
\hline
\end{tabular}

Source: SPSS output results, 2020

It can be seen the results of the Kolmogorov-Smirnov One Sample test which shows that the Asymp.Sig value is obtained. of 0.072. Because the value of Asymp.Sig. greater than 0.05, it can be concluded that the research model is normally distributed and can be continued to the next test.

\section{Multicollinearity Test}

Multicollinearity test was conducted to see whether the independent variable and the dependent variable had a relationship or there was a correlation. The multicollinearity test in this study was calculated using the Variance Inflation Factor (VIF). If the VIF value is $<10$ and the tolerance value is greater than 0.01 , multicollinearity will not occur. The results of the multicollinearity test can be seen in table 4 which is presented below:

Table 4

Multicollinearity Test Results

Coefficients

\begin{tabular}{|l|l|l|l|}
\hline Model & Tolerance & VIF & Keterangan \\
\hline X1_Gender & .953 & 1.049 & No Multicollinearity \\
\hline X2_Audit Committee & .930 & 1.076 & No Multicollinearity \\
\hline X3_Leverage & .897 & 1.115 & No Multicollinearity \\
\hline X4_Profitability & .920 & 1.087 & No Multicollinearity \\
\hline X5_Firm Size & .950 & 1.052 & No Multicollinearity \\
\hline
\end{tabular}

Source: SPSS output results, 2020 


\section{International Journal of Economics, Business and Management Research}

Vol. 6, No.01; 2022

ISSN: $2456-7760$

From the test results in table 4 it can be seen that the tolerance value for the gender variable is 0.953 , the audit committee is 0.930 , the leverage is 0.897 , the profitability is 0.920 and the firm size is 0.950 and the VIF value for the gender variable is 1.049 , the audit committee is 1.076 , leverage is 1.115 , profitability is 1.087 , and company size 1.052 . It can be seen if the tolerance value for all independent variables is $>0.1$ and the VIF of all independent variables shows a small number with a range of 1,049 to 1,115 , which means that the VIF is less than 10 . It can be stated that the regression model in this study does not occur multicollinearity.

\section{Heteroscedasticity Test}

Heteroscedasticity test was conducted to test whether in the regression model there is an inequality of variance from the residuals of one observation period to another observation period. The heteroscedasticity test in this study uses the Glejser test which is used to detect the presence or absence of heteroscedasticity by regressing the independent variable to the absolute residual. If the significance level of the independent variable is $>0.05$ then there is no heteroscedasticity in the regression model and vice versa. If the result does not occur heteroscedasticity then it is a good regression model. The results of the heteroscedasticity test can be seen in table 5 which is presented below:

Table 5

Glejser Test Results

Coefficient

\begin{tabular}{|l|l|}
\hline Model & Sig. \\
\hline (Constant) & .451 \\
\hline X1_Gender & .492 \\
\hline X2 Audit Committee & .418 \\
\hline X3_Leverage & .207 \\
\hline X4_Profitability & .190 \\
\hline X5_Firm Size & .319 \\
\hline
\end{tabular}

Source: SPSS output results, 2020

From the results of the heteroscedasticity test with glejser in table 5 , a significant value (p-value) on the gender variable is 0.492 , the audit committee is 0.418 , leverage is 0.207 , profitability is 0.190 and company size is 0.319 . All independent variables above $>0.05$, it can be stated that the regression model does not occur heteroscedasticity.

\section{Autocorrelation Test}

Autocorrelation test shows the level of relationship between variables. If two variables influence each other and have a reciprocal relationship, it can be said to have a correlational relationship. In the autocorrelation test performed using Durbin Watson (DW), if DW is greater than the value of $\mathrm{du}$ and less than the value of $4-\mathrm{du}(\mathrm{du}<\mathrm{DW}<(4-\mathrm{du}))$ then this regression model does not experience autocorrelation. The results of the autocorrelation test can be seen in table 6 which is presented below: 
Vol. 6, No.01; 2022

ISSN: $2456-7760$

Table 6
Autocorrelation Test Results
Model Summary
\begin{tabular}{|l|l|}
\hline Model & $\begin{array}{l}\text { Durbin- } \\
\text { Watson }\end{array}$ \\
\hline 1 & 2.089 \\
\hline
\end{tabular}

Source: SPSS output results, 2020

From the results of the autocorrelation test in table 6, the Durbin Watson (DW) value is 2,089. The value of $\mathrm{DW}$ proves that $\mathrm{n}=128, \mathrm{k}=5$ obtained $\mathrm{DU}=1.802$, then $(4-\mathrm{DU})=2.198$. Thus the value of DW (2.089) is between the values of DU $=1.802$ san $(4-D U)=2.198$, so it can be stated that the regression model does not experience autocorrelation.

\section{Hypothesis testing}

\section{Multiple Linear Regression Analysis}

Multiple linear regression analysis was used to determine the effect of the independent variable (X) simultaneously or partially, namely gender, audit committee, leverage, profitability, and firm size on the dependent variable (Y), namely tax avoidance. In this test will also be tested simultaneously (F test) or partially ( $\mathrm{T}$ test) and test the coefficient of determination (R2). The results of this test can be seen in table 7 which is presented below:

Table 7

Multiple Linear Regression Analysis Results

Coefficients

\begin{tabular}{|l|l|l|l|}
\hline \multirow{2}{*}{ Model } & \multicolumn{2}{|l|}{ Unstandardized Coefficient } & $\begin{array}{l}\text { Standardized } \\
\text { Coefficient }\end{array}$ \\
\cline { 2 - 4 } & Beta & Std. Error & Beta \\
\hline (Constant) & -.098 & .091 & \\
\hline X1_Gender & .015 & .008 & .170 \\
\hline X2 Audit Committee & .060 & .016 & .323 \\
\hline X3_Leverage & -.008 & .006 & -.118 \\
\hline X4_Profitability & -.008 & .024 & -.027 \\
\hline X5_Firm Size & .006 & .003 & .199 \\
\hline
\end{tabular}

Source: SPSS output results, 2020

Based on the multiple linear regression analysis above, it can be stated in the model equation as follows:

$\mathrm{Y}=-\mathbf{0 . 0 9 8}+0.015 \mathrm{X} 1+0.060 \mathrm{X} 2-0.008 \mathrm{X} 3-0.008 \mathrm{X} 4+0.006 \mathrm{X} 5$

Based on the results of the regression equation model above, the following conclusions can be drawn: 


\section{International Journal of Economics, Business and Management Research}

Vol. 6, No.01; 2022

ISSN: $2456-7760$

1. The value of constant (a) is -0.098 , which means that if the value of all independent variables is constant or 0 , then there is a tax avoidance of -0.098 . If there are no variables of gender, audit committee, leverage, profitability, and company size that affect tax avoidance, then the tax avoidance effort will be 0.098 units.

2. The regression coefficient value of the gender variable is 0.015 which means that if the gender variable increases one unit with the assumption that the other independent variables are fixed, there will be an increase in tax avoidance of 0.015

3. The regression coefficient value of the audit committee variable of 0.060 means that if the audit committee variable increases by one unit with the assumption that the other independent variables are fixed, there will be an increase in tax avoidance of 0.060 .

4. The value of the leverage regression coefficient of -0.008 means that if the leverage variable increases by one unit assuming the other independent variables are fixed, there will be a decrease in tax avoidance of 0.008 .

5. The value of the profitability regression coefficient of -0.008 means that if the profitability variable increases by one unit with the assumption that the other independent variables are fixed, there will be a decrease in tax avoidance of 0.008 .

6. Firm size regression coefficient value of 0.006 means that if the firm size variable increases by one unit assuming other independent variables remain, there will be an increase in tax avoidance of 0.006 .

\section{F. Significance Test}

The F test is used to see the feasibility level of the study. If the significance value is less than 0.05 , it means that the hypothesis is accepted and passes the model feasibility test, so that the regression model is feasible to be used as the basis for analysis. And if the significance value is more than 0.05 then the hypothesis is rejected and does not pass the model feasibility test so that the regression model is not feasible to be used as a basic reference for analysis. The results of the F significance test can be seen in table 8 which is presented below:

Table 8

F Significance Test Results ANOVA

\begin{tabular}{|l|l|l|}
\hline Model & F & Sig. \\
\hline Regression & 5.191 & .000 \\
\hline
\end{tabular}

Source: SPSS output results, 2020

From the results of the $\mathrm{F}$ significance test in table 8 above, a significance value of $0.000<0.05$ is obtained, it can be stated that the hypothesis is accepted and passes the model feasibility test, so that the regression model is feasible to be used as a basic reference for analysis. 
Vol. 6, No.01; 2022

ISSN: $2456-7760$

\section{Coefficient of Determination Test (R2)}

The coefficient of determination test describes the ability of the model used to explain the variations that occur in the dependent variable. If the result of R2 is close to 1 (one), then the result indicates a strong correlation between the independent variable and the dependent variable. However, if the value of R2 is close to 0 (zero), then the correlation between the independent and dependent variables is weak (Ghozali, 2013). The results of the coefficient of determination test can be seen in table 9 which is presented below:

Table 9

Coefficient of Determination Test Results

Model Summary

\begin{tabular}{|l|l|l|ll|}
\hline Model & $\mathrm{R}$ & R Square & $\begin{array}{l}\text { Adjusted } \\
\text { Square }\end{array}$ & R. \\
\hline 1 & .419 & .175 & .142 \\
\hline
\end{tabular}

Source: SPSS output results, 2020

From the results of the coefficient of determination test in the table above, it is obtained a value of 0.142 which means that the tax avoidance variable of $14.2 \%$ can be influenced by the variables of gender, audit committee, leverage, profitability, and company size.

\section{Individual Parameter Significance Test (T Test)}

$T$ statistical test is used to determine how far the influence of one independent variable in partially explaining the variation of the dependent variable. In decision making, if the significance value is $>0.05$, it means that the independent variable has no effect on the dependent variable, and if the significance value is $<0.05$, it means that the independent variable has a significant effect on the dependent variable. The results of the T test can be seen in table 10 below:

Table 10

T. Test Results

Coefficient

\begin{tabular}{|l|l|l|l|l|}
\hline \multirow{2}{*}{ Model } & \multicolumn{2}{|l|}{$\begin{array}{l}\text { Unstandardized } \\
\text { Coefficient }\end{array}$} & \multirow{2}{*}{ Sig. } \\
\cline { 2 - 3 } & Beta & $\begin{array}{l}\text { Std. } \\
\text { Error }\end{array}$ & & \\
\hline (Constant) & -.098 & .091 & -1.074 & .285 \\
\hline X1_Gender & .015 & .008 & 2.018 & .046 \\
\hline X2_Audit Committee & .060 & .016 & 3.789 & .000 \\
\hline X3_Leverage & -.008 & .006 & -1.360 & .176 \\
\hline X4_Profitability & -.008 & .024 & -.317 & .752 \\
\hline X5_Firm Size & .006 & .003 & 2.362 & .020 \\
\hline
\end{tabular}

Source: SPSS output results, 2020 


\section{International Journal of Economics, Business and Management Research}

Vol. 6, No.01; 2022

ISSN: $2456-7760$

From the results of the $\mathrm{T}$ test in the table above, the following tests are obtained:

1. First Hypothesis Testing

In this study, the first hypothesis states that gender has a positive effect on tax avoidance. It can be seen in table 10 that the magnitude of the gender regression coefficient is 0.015 with a significance of 0.046. At the significance level $=0.05$, then $=0.046<0.05$, which means the regression coefficient is significant, so it can be concluded that gender has a significant positive effect on tax avoidance and this hypothesis is accepted.

\section{Second Hypothesis Testing}

The second hypothesis states that the audit committee has a positive influence on tax avoidance. It can be seen in table 10 that the magnitude of the audit committee's regression coefficient is 0.060 with a significance of 0.000 . This means that the regression coefficient is significant because $=0.000<0.05$, so it can be concluded that the audit committee has a significant positive effect on tax avoidance and this hypothesis is accepted.

\section{Third Hypothesis Testing}

The third hypothesis states that leverage has a positive effect on tax avoidance. It can be seen in table 10 the magnitude of the leverage regression coefficient is -0.008 with a significance of 0.176 . This means that the regression coefficient is not significant because $=0.176>0.05$, so it can be concluded that leverage has no effect on tax avoidance and this hypothesis is rejected.

\section{Fourth Hypothesis Testing}

The fourth hypothesis states that profitability has a negative effect on tax avoidance. It can be seen in table 10 that the magnitude of the profitability regression coefficient on tax avoidance is 0.008 with a significance of 0.752 . This means that the regression coefficient is not significant because $=0.752>0.05$, so it can be concluded that profitability has no effect on tax avoidance and this hypothesis is rejected.

\section{Fifth Hypothesis Testing}

The fifth hypothesis states that firm size has a positive effect on tax avoidance. it can be seen in table 10 the relationship between company size and tax avoidance is 0.006 with a significance of 0.020 . This means that the regression coefficient is significant because $=0.020<0.05$, so it can be concluded that firm size has a significant positive effect on tax avoidance and this hypothesis is accepted.

Based on the results of hypothesis testing above, it can be concluded that the variables of gender, audit committee and firm size have a significant positive effect on tax avoidance, while leverage and audit committee variables have no effect on tax avoidance.

\section{Discussion}

\section{The Effect of Gender on Tax Avoidance}

From the test results between the variables gender and tax avoidance can be obtained a significance level of $0.046<0.05$. The significance value of the gender variable is less than 0.05 


\section{International Journal of Economics, Business and Management Research}

Vol. 6, No.01; 2022

ISSN: $2456-7760$

with a t-value of 2.018 so it can be stated that the gender variable has a significant effect on tax avoidance. This result is in accordance with the first hypothesis which states that gender has a significant positive effect on tax avoidance. This means that the higher the proportion of women's position in the company, the higher the tax avoidance by the company and thus $\mathrm{H} 1$ is accepted.

When associated with feminism theory, gender differences between men and women will make a person's character and behavior in decision-making also different. An increase in the proportion of women who occupy high positions in the company will influence decision making in various fields, one of which is taxation. Many companies want their companies to have good governance, in this case a more proportion of women's positions on the board of commissioners and directors are needed because women tend to be more careful in taking risks so they can avoid risk in decision making.

The company will appear to have performed well when there is a proportion of female and male boards. The more diverse the proportion of women and men, the better the company's performance and the better its management performance. Companies that have different gender proportions or have at least one female board of commissioners or directors will increase company efficiency through tax avoidance. According to Robinson \& Dechant (1997) companies that have at least 1 female board of commissioners or directors are considered to have more skills related to company operations and other policies, these skills will affect the amount of tax that will be paid by the company and will increase the company's tax avoidance ability.

Women have a higher obedience attitude than men, this will make women more afraid of investors if the company looks bad and the value of the company decreases. This fear will influence women to take tax evasion. By avoiding tax, corporate profits will increase and can give a positive impression on the company's performance, so that the company will look good in the eyes of investors and investors will positively assess the performance and value of the company.

It can be concluded that an increase in the proportion of women on the board of commissioners or directors will have a tendency to practice tax avoidance, because women are more obedient and avoid risks to investors. This is used to reduce the tax burden by minimizing tax payments through tax avoidance.

These results are consistent with research conducted by Amri (2017) and supported by Winasis \& Yuyetta (2017) which stated that gender has a positive effect on tax avoidance.

\section{Influence of the Audit Committee on Tax Avoidance}

From the test results between the audit committee variable and tax avoidance, it can be obtained that the $t$ value of 3.789 has a significance level of $0.000<0.05$. The significance value of the audit committee variable is less than 0.05 so it can be stated that the audit committee variable has a significant positive effect on tax avoidance. This result is in accordance with the second hypothesis which states that the audit committee has a positive effect on tax avoidance and thus $\mathrm{H} 2$ is accepted. 


\section{International Journal of Economics, Business and Management Research}

Vol. 6, No.01; 2022

ISSN: $2456-7760$

Based on the IDX circular number SE008/BEJ/12-2001 regarding the membership of the audit committee, it is stated that there must be at least 3 members of the company's audit committee, including the chairman of the audit committee. The audit committee is appointed and dismissed by the company's board of commissioners, therefore the structure and selection of audit committee membership is the responsibility of the board of commissioners. Companies with a large number of audit committees but holding a small frequency of meetings will tend to provide ineffective financial oversight and monitoring. The existence of pressure from the board of commissioners will also make the audit committee ignore the performance of managers in compiling financial reports so that their performance is not optimal and managers can do tax avoidance easily. So that the more audit committees, the more tax avoidance.

These results are consistent with the research conducted by Sarra (2017) and Mulyani et al., (2018) which stated that the audit committee had a positive effect on tax avoidance.

\section{The Effect of Leverage on Tax Avoidance}

From the test results between the variable leverage and tax avoidance can be obtained a significance level of $0.176>0.05$. The significance value of the leverage variable is greater than 0.05 with a t value of -1.360 so it can be stated that the leverage variable has no significant effect on tax avoidance. This is not in accordance with the third hypothesis which states that leverage has a positive effect on tax avoidance and thus $\mathrm{H} 3$ is rejected. or not proven.

Companies use leverage to measure and determine the ratio of the company's debt, both short term and long term. Management does not use leverage to avoid tax because high or low leverage has no effect on the company, management will always make tax avoidance efforts to maintain good relations with investors through the presentation of taxable income that is always optimal and a balanced capital structure so that investors will assess the company's performance well and investor confidence will be maintained. So, it can be seen that the level of leverage has no effect on tax avoidance by the company.

The results of this study are in accordance with research conducted by Dewinta \& Setiawan (2016) and Mariani (2020) which stated that leverage had no effect on tax avoidance.

\section{The Effect of Profitability on Tax Avoidance}

From the test results between profitability and tax avoidance variables can be obtained a significance value of $0.752>0.05$. The significance value of the profitability variable is greater than 0.05 with a t count of -0.317 so it can be stated that profitability has no significant effect on tax avoidance. These results state that profitability has no significant effect on tax avoidance and thus $\mathrm{H} 4$ is rejected or not proven.

This study shows that, high and low ROA is not a determinant of tax avoidance actions taken by the company, because the company's management will always try to develop a strategy to develop its business. Management uses company cash to finance existing operational activities and maximize company performance in order to generate stable profits. Therefore, management avoids tax to save the cash so that the company will reduce the tax burden paid. 


\section{International Journal of Economics, Business and Management Research}

Vol. 6, No.01; 2022

ISSN: $2456-7760$

This is also done by management so that it is easy to evaluate and take policies to develop business within the company. If management does not avoid tax, the tax burden that must be paid by the company will be large and the company is judged by investors to be unable to manage the resources owned by the company. So, it can be seen that high or low profitability has no effect on corporate tax avoidance because management will still do tax avoidance.

These results are in accordance with research conducted by Nugrahitha \& Suprasto (2018) and Marpaung \& Sudjiman (2020) that profitability had no effect on tax avoidance.

\section{The Effect of Firm Size on Tax Avoidance}

From the test results between company size variables on tax avoidance, it can be obtained a significance level of $0.020<0.05$. The significance value of the firm size variable is smaller than 0.05 with a $t$ count of 2.362 so it can be stated that firm size has a significant effect on tax avoidance. This is in accordance with the fifth hypothesis which states that firm size has a significant positive effect on tax avoidance and thus H5 is accepted.

When connected with agency theory, the difference in interests between managers and shareholders makes fraudulent acts that have been committed. The company has the resources and can be used to increase the performance compensation obtained by the agent by reducing the income tax burden. This is done by the agent to maximize the company's performance.

In Indonesia, the tax system is used, namely the self-assessment system. This system allows companies to calculate and report their own taxes. The existence of this system is used by agents in the company, namely managers to manipulate taxable income to make it smaller than the actual condition, so that the tax burden borne by the company will be smaller, and the tax that must be paid by the company will be smaller Ardyansyah (2014).

Companies with large amounts of assets will have larger and more operational activities and reflect better company performance in the long term when compared to companies with small assets. The larger the size of the company's assets, the greater the resources owned by the company. Companies are able to utilize assets and manage existing resources to generate greater profits than companies with small assets.

The increase in company profits is certainly accompanied by an increase in the income tax burden that must be paid by the company. This encourages companies to do tax avoidance so that the burden on the company is not getting bigger and the taxes that must be paid by the company will be smaller. Therefore, managers will take advantage of the company's assets and resources in order to reduce the company's tax burden so that companies with large assets will do tax avoidance.

So it can be explained that the bigger the company, the manager will do tax avoidance by managing the tax burden. Rego (2003) explained that it will be easier for companies to practice tax avoidance if the size of the company is large and growing so that financial transactions are increasingly complex. Therefore, companies take advantage of this to do tax avoidance. 


\section{International Journal of Economics, Business and Management Research}

Vol. 6, No.01; 2022

ISSN: $2456-7760$

These results are in accordance with research conducted by Mulyani et al., (2019) and Nur \& Subardjo (2020) that firm size had a positive effect on tax avoidance.

\section{Conclusions and Suggestions}

Based on the results of the analysis and discussion that have been carried out, it can be concluded that gender has a significant positive effect on tax avoidance. In this study, the greater the proportion of women on the board of commissioners and directors, the greater the tendency for tax avoidance to be. For the second variable namely audit committee, it has a significant positive effect on tax avoidance. Because the audit committee does not work optimally due to pressure from the board of commissioners, and the presence of more audit committees will make them work ineffectively so that the more audit committees, the more tax avoidance. On Leverage variable, it has no effect on tax avoidance. This means that the level of leverage has no effect on tax avoidance. Profitability has no effect on tax avoidance. High and low profitability has no effect on tax avoidance. Finally, Firm size has a significant positive effect on tax avoidance. The greater the total assets owned by the company, the greater the company's efforts to avoid tax.

This research has been prepared correctly and in accordance with scientific procedures, but still has limitations that can be used as a reference for further research in order to obtain better results. The limitation of this study is that the measurement of the audit committee is only seen from the number of audit committees in the company. So that for the future research, it may consider the quality of the audit committee by using a scoring of the level of education and competence.

\section{References}

Alfaruqi, H. A., Sugiharti, D. K., \& Cahyadini, A. (2019). PERAN PEMERINTAH DALAM MENCEGAH TINDAKAN PENGHINDARAN PAJAK SEBAGAI AKTUALISASI PENYELENGGARAAN PEMERINTAHAN YANG BAIK DALAM BIDANG PERPAJAKAN. Jurnal Ilmu Hukum Kenotariatan Fakultas Hukum Unpad, 113-133.

Amri, M. (2017). "Pengaruh Kompensasi Manajemen Terhadap Penghindaran Pajak dengan Moderasi Diversifikasi Gender dan Prefrensi Risiko Eksekutif Perusahaan di Indonesia." Jurnal Aset (Akuntansi Riset, 9 (1): 1-14.

Ardyansyah, D. (2014). "Pengaruh Size, Leverage, Profitability, Capital Intensity Ratio dan Komisaris Independen Terhadap Effective Tax Rate (ETR).” Skripsi, Semarang: Universitas Diponegoro.

Armstrong, C. S., Blouin, J. L., Jagolinzer, A. D., \& Larcker, D. F. (2015). "Corporate Governance, Incentives, And Tax Avoidance." Journal of Accounting and Economics, 60 (1): $1-17$.

Asmaeny, A. (2007). Feminisme Profetik. Yogyakarta: Kreasi Wacana.

CNBCIndonesia.com. (2020). https://www.cnbcindonesia.com/news/20200108133413-4128546/hmm-sudah-11-tahun-ri-tak-mampu-capai-target-pajak. 


\section{International Journal of Economics, Business and Management Research}

Vol. 6, No.01; 2022

ISSN: $2456-7760$

Budianti, S., \& Curry, K. (2018). "Pengaruh Profitabilitas, Likuiditas, dan Capital Intensity Terhadap Penghindaran Pajak (Tax Avoidance)." In Prosiding Seminar Nasional Cendekiawan, (pp. 1205-1209).

Cahyadi, I. G. L. N. D., \& Merkusiwati, N. K. L. A. (2016). "Pengaruh Komisaris Independen, Leverage, Size dan Capital Intensity Ratio pada Tax Avoidance." E-Jurnal Akuntansi, 17(1): 690-714.

Darmawan, I. G. H., \& Sukartha, I. M. 2014. "Pengaruh Penerapan Corporate Governance, Leverage, ROA, dan Ukuran Perusahaan pada Penghindaran Pajak.” E-Jurnal Akuntansi 9 (1): 143-161.

Dayanara, L., Titisari, K. H., \& Wijayanti, A. (2020). Pengaruh Leverage, Profitabilitas, Ukuran Perusahaan, dan Capital Intensity Terhadap Penghindaran Pajak pada Perusahaan Barang Industri Konsumsi yang Terdaftar di BEI tahun 2014-2018. Jurnal Akuntansi dan Sistem Teknologi Informasi, 15 (3).

Dewi, G. A., \& Sari, M. M. (2015). "Pengaruh Insentif Eksekutif, Corporate Risk dan Corporate Governance pada Tax Avoidance." E-Jurnal Akuntansi, 13 (1): 50-67.

Dewinta, I. A. R. dan Setiawan, P. E. (2016). "Pengaruh Ukuran Perusahaan, Umur Perusahaan, Profitabilitas, Leverage, dan Pertumbuhan Penjualan Terhadap Tax Avoidance.” EJurnal Akuntansi Universitas Udayana, 14 (3): 1584-1613.

Luthans, Fred. (2006). Perilaku Organisasi. Edisi Sepuluh, Yogyakarta: Andi

Ghozali, Imam. (2011). Aplikasi Analisis Multivariate dengan Program IBM SPSS 21. Update PLS Regresi. Semarang: Badan Penerbit Universitas Diponegoro.

Ghozali, Imam. (2013). Aplikasi Analisis Multivariate dengan Program SPSS. Semarang: Badan Penerbit Universitas Diponegoro.

Hadi, Syamsul. (2009). Metodologi Penelitian Kuantitatif Untuk Akuntansi Dan Keuangan. Yogyakarta: Ekonesia.

Hanafi. 2004. Manajemen Keuangan. Yogyakarta: BPFE UGM.

Jensen, Michael C. dan W.H. Meckling. (1976). Theory of The Firm: Managerial Behavior, Agency Cost and Ownership Structure. Journal of Financial Economics 3. Hal 305-360.

Kamayanti, A. (2013). "Riset Akuntansi Kritis: Pendekatan (Non) Feminisme Tjoet Njak Dhien." Jurnal Akuntansi Multiparadigma, 4 (3): 361-375.

Kurniasih, T., \& Sari, M. M. R. (2013). "Pengaruh Return On Assets, Leverage, Corporate Governance, Ukuran Perusahaan dan Kompensasi Rugi Fiskal pada Tax Avoidance." Buletin Studi Ekonomi, 1(18): 58-66.

Kusumastuti, S., Supatmi, S., \& Sastra, P. (2008). "Pengaruh Board Diversity terhadap Nilai Perusahaan dalam Perspektif Corporate Governance." Jurnal Akuntansi dan Keuangan, 9(2): pp-88.

Mariani, D. (2020). "Faktor Yang Memengaruhi Tax Avoidance Pada Perusahaan Barang Konsumsi Yang Terdaftar Di BEI.” Jurnal Ilmiah Akuntansi Kesatuan, 8(3): 253-262. 


\section{International Journal of Economics, Business and Management Research}

Vol. 6, No.01; 2022

ISSN: $2456-7760$

Marpaung, N., \& Sudjiman, P. E. (2020). "Pengaruh Profitabilitas Dan Leverage Terhadap Penghindaran Pajak Perusahaan Sub-Sektor Kimia Yang Terdaftar Pada Bursa Efek Indonesia Periode 2017-2019." Jurnal Ekonomis 13(4b).

Masri, Indah dan Martani, Dwi. 2013. "Pengaruh Tax Avoidance Terhadap Cost Of Debt". Simposium Nasional Akuntansi XV, Banjarmasin 20 -23 September 2012

Melisa, M. \& Tandean, V. A. (2015). "Faktor-Faktor yang Mmemengaruhi Penghindaran Pajak (Tax Avoidance)." Jurnal Akuntansi Bisnis 8(1).

Mitnick, Barry M. 2013. "Origin of the Theory of Agency: An Account by One of the Theory's Originators." In Pittsburgh.

Mulyani, S., Wijayanti, A., \& Masitoh, E. (2018). "Pengaruh Corporate Governance terhadap Tax Avoidance Perusahaan Pertambangan yang Terdaftar di BEI." Jurnal Riset Akuntansi Dan Bisnis Airlangga, 3(1).

Mustikasari, E. (2007). "Kajian Empiris tentang Kepatuhan Wajib Badan di Perusahaan Industri Pengilahan Surabaya." Simposium Nasional Akuntansi X 26.

Nasional.kontan.co.id. (2020). https://nasional.kontan.co.id/news/dirjen-pajak-angkat-bicarasoal-kerugian-rp-687-triliun-dari-penghindaran-

pajak\#: :text=Temuan\%20tersebut\%20diumumkan\%20oleh\%20Tax,dollar\%20Amerika $\% 20$ Serikat\%20(AS).

Nasional.kontan.co.id. (2014). https://nasional.kontan.co.id/news/coca-cola-diduga-akalisetoran- pajak

Ngadiman, N., \& Puspitasari, C.(2017). "Pengaruh Leverage, Kepemilikan Institusional, Dan Ukuran Perusahaan Terhadap Penghindaran Pajak (Tax Avoidance) Pada Perusahaan Sektor Manufaktur Yang Terdaftar Di Bursa Efek Indonesia 2010-2012. Jurnal Akuntansi 18(3): 408-421.

Novita, N. (2016). "Executives Characters, Gender and Tax Avoidance: A Study on Manufacturing Companies in Indonesia." In 2016 Global Conference on Business, Management and Entrepreneurship (pp 92-95). Atlantis Press.

Noviyani, Espi. (2019). "Pengaruh Return on Assets, Leverage, Ukuran Perusahaan, Intensitas Aset Tetap, Dan Kepemilikan Institusional Terhadap Penghindaran Pajak (Studi Empiris Pada Perusahaan Manufaktur yang Terdaftar di BEI periode 2015-2017." Skripsi, Universitas Diponegoro.

Nugrahitha, I. M. A., \& Suprasto, H. B. (2018). "Pengaruh Profitabilitas, Leverage, Corporate Governance, dan Karakter Eksekutif pada Tax Avoidance." E-Jurnal Akuntansi 22(3).

Nur, M., \& Subardjo, A. (2020). "Pengaruh Mekanisme Good Corporate Governance, Profitabilitas, Likuiditas, dan Ukuran Perusahaan Terhadap Tax Avoidance." Jurnal Ilmu dan Riset Akuntansi (JIRA) 9(6).

Okta Arianti, Dessy. (2013). "Analisis Uji Kesesuaian Proses Penyusunan Anggaran Pada Badan Layanan Umum Terhadap Peraturan Pemerintah Dan Undang-Undang (Studi 


\section{International Journal of Economics, Business and Management Research}

Vol. 6, No.01; 2022

ISSN: $2456-7760$

Kasus Pada Lembaga Pengelola Dana Bergulir Koperasi Dan Usaha Mikro Kecil Menengah-Kementrian Koperasi Dan Usaha Kecil Menengah)."

Pohan, Chairil Anwar. (2011). Manajemen Perpajakan Strategi Perencanaan Pajak dan Bisnis. Jakarta: PT Gramedia Pustaka Utama.

Pohan, Chairil Anwar. (2013). Manajemen Perpajakan (Strategi Perencanaan Pajak dan Bisnis). Edisi Revisi. Jakarta: PT Gramedia Pustaka Utama

Prakosa, K. B. (2014). "Pengaruh Profitabilitas, Kepemilikan Keluarga, dan Corporate Governance Terhadap Penghindaran Pajak di Indonesia." Simposium Nasional Akuntansi, 17(2): 24-27.

Putra, M. A. Andreas, \& Nasrizal. (2018). "Pengaruh Karakter Eksekutif, Kompensasi Eksekutif, Gender Diversity, Koneksi Politik, Debt To Equity Ratio Terhadap Penghindaran Pajak Dan Manajemen Laba Sebagai Variabel Intervening." Jurnal Ekonomi 26 (4): 52-71.

Rahayu, N. (2011). "Evaluasi Regulasi Atas Praktik Penghindaran Pajak Penanaman Modal Asing." Jurnal Akuntansi Keuangan 7(1): 61-78.

Rego, S. (2003). "Tax Avoidance Activities of U.S. Multinational Corporations. Contemporary Accounting Research, 20(4): 805-833.

Regulation of the Financial Services Authority Formation and Guidelines for the Work Implementation of the Audit Committee. 2015. Indonesia

Rifai, A., \& Atiningsih, S. 2019. "Pengaruh Leverage, Profitabilitas, Capital Intensity, Manajemen Laba Terhadap Penghindaran Pajak." ECOBANK. Journal of Economics and Banking, I(2): 135-142.

Robinson, G. \& Dechant, K. (1997). "Building a business case for diversity". Academy of Management Executive, 11(3): 21-30.

Saifudin, \& Yunanda, D. (2016). "Determinasi Return on Assets, Leverage Corporate Governance, Ukuran Perusahaan dan Kompensasi Rugi Fiskal dan Kepemilikan Institusi Terhadap Penghindaran Pajak.” WIGA: Jurnal Penelitian Ilmu Ekonomi, 6(2): 131-143.

Sarra, H. D. (2017). "Pengaruh Konservatisme Akuntansi, Komite Audit, dan Dewan Komisaris Independen terhadap Penghindaran Pajak (Studi Empiris Pada Industri Kimia dan Logam di Bursa Efek Indonesia Periode 2010-2014." Competitive, 1(1): 63-86.

Sari, N., Luthfab, E., \& Syafriyeni, N. (2020). "Pengaruh Profitabilitas, Leverage, Komisaris Independen, Kepemilikan Institusional, dan Ukuran Perusahaan terhadap Penghindaran

Pajak pada Perusahaan Manufaktur yang Terdaftar di Bursa Efek Indonesia pada tahun 2014-2018." Jurnal Ilmiah Universitas Batanghari Jambi, 20 (2): 376-387.

Sartono, Agus. (2010). Manajemen Keuangan Teori dan Aplikasi. Edisi 4. Yogyakarta: BPFE

Stiglitz, Joseph E. 1986. THE GENERAL THEORY OF TAX AVOIDANCE.

Tessa G. C., \& Harto, P. (2016). Fraudulent Financial Reporting: Pengujian Teori Fraud Pentagon Pada Sektor Keuangan Dan Perbankan Di Indonesia. Simposium Nasional Akuntansi XIX. Lampung: Simposium Nasional Akuntasi XIX. 
Vol. 6, No.01; 2022

ISSN: $2456-7760$

Undang-Undang Republik Indonesia No 28 Tahun 2007 Perubahan Ketiga atas Undang-

Undang No 6 Tahun 1983 Tentang Ketentuan Umum dan Tata Cara Perpajakan, http://www.dpr.go.id/dokjdih/document/uu/UU_2007_28.pdf.

Waluyo. (2011). Akuntansi Pajak. Jakarta: Salemba Empat.

Warih, A. A. (2019). "The Effecr of Firm Size and Audit Committee Towards Companies Tax Avoidance." Eurasia: Economics \& Business, 7(25), 2019-06.

Wijayanti, Y. C., \& Merkusiwati, N. K. L. A. (2017). "Pengaruh Proporsi Komisaris Independen, Kepemilikan Institusional, Leverage, dan Ukuran Perusahaan pada Penghindaran Pajak." E-Jurnal Akuntansi, 20(1): 699-728.

Winasis, S. E., \& Yuyetta, E. N. A. (2017). "Pengaruh Gender Diversity Eksekutif Terhadap Nilai Perusahaan Tax Avoidance Sebagai Variabel Intervening: Studi Kasus Pada Perusahaan Pertambangan Yang Terdaftar di BEI Tahun 2012-2015." $\quad$ Diponegoro Journal of Accounting, 6(1): 311-324.

Winata, F. (2014). "Pengaruh Corporate Governance Terhadap Tax Avoidance Pada Perusahaan Yang Terdaftar Di Bursa Efek Indonesia Tahun 2013.” Tax Accounting \& Review, 4(1): 162.

Wollstonecraft, Mary, 1792. A Vindication of the Rights of Woman.

Yulianti, Reny, Dedi Dwi Putra, and Pulus Diki Takanjanji. 2018. "Women Leadership: Telaah Kapasitas Perempuan Sebagai Pemimpin." MADANI Jurnal Politik dan Sosial Kemasyarakatan. 